\title{
Relationship between stride characteristics and scores in dressage tests
}

\author{
Sophie Biau and Eric Barrey ${ }^{7}$ \\ Ecole Nationale d'Equitation Terrefort, Saumur and Université d'Evry - Département Biologie', France
}

\begin{abstract}
Summary
The purpose of this study was to describe the relationship between the scores of dressage horses in competition and gait characteristics. During twenty five dressage tests, eighteen horses were tested with a gait analysis system. According to the level of the dressage test, two groups of horses were used: a group of ten young horses $(4,5$ and 6 year old) and a group of eight experienced horses $(7,8,9,11$ and 13 year old). An accelerometric device fixed at the sternum measured the dorsoventral and longitudinal accelerations. Stride frequency, symmetry, regularity, dorsoventral displacement, longitudinal activity, dorsoventral activity, vector of propulsion and vector of braking were calculated from horse accelerations for each figure of dressage test. At the same time, the judges marked all the figures. Judges' sheets were collected to calculate correlations between marks, total score, and gait variables measured during the test. The results showed that specific characteristics of the walk and trot were required in young horses. The trot should be slow with a large dorsoventral displacement and a large longitudinal activity. The walk should be slow, regular, symmetric, with a large dorsoventral activity and dorsoventral displacement. A good movement performed at the canter was indicated by high longitudinal and dorsoventral activities. Few correlations for the group of experienced horses were observed.
\end{abstract}

Keywords: kinetics; dressage; judge; marks; test

\section{Korrelation zwischen kinetischen Gangcharakteristika und der Benotung von Dressuraufgaben}

Ziel der Arbeit war die Untersuchung von Korrelationen zwischen der sportrichterlichen Benotung von Dressuraufgaben im Wettkampf und den entsprechenden Gangcharakteristika. Während fünfundzwanzig Dressuraufgaben wurden achtzehn junge Pferde mit einem Ganganalysesystem untersucht. Diese Pferde wurden je nach Wettkampf in zwei Gruppen eingeteilt: 4, 5 und 6 jährige Pferde sowie ältere, erfahrene Pferde. Ein im Bereich des Brustbeins fixierter Beschleunigungsmesser maß die dorsoventralen und longitudinalen Beschleunigungen. Schrittfrequenz, Symmetrie, Regelmäßigkeit, dorsoventrale Bewegung, longitudinale und dorsoventrale Aktivität, Beschleunigung und Verzögerung wurden für jede Dressuraufgabe berechnet.Gleichzeitig bewerteten die Dressurrichter die Aufgaben. Die Benotungen wurden gesammelt, um die Zusammenhänge zwischen der Bewertung der Dressuraufgaben und der Gangart, dem Gesamtergebnis und den kinetisch gemessenen Gangkomponenten zu berechnen. Die Ergebnisse zeigen, dass bei jungen Pferden spezifischen Merkmale von Schritt und Trab gefordert werden. Der Trab sollte langsam sein mit ausgeprägter dorsoventraler Bewegung und deutlicher longitudinaler Aktivität. Der Schritt sollte langsam, regelmäßig und symmetrisch sein, mit deutlicher dorsoventraler Bewegung und Aktivität. Der Galopp war durch ausgeprägte longitudinale und dorsoventrale Aktivitäten charakterisiert. Für die Gruppe der erfahrenen Pferde wurden allerdings nur wenige Zusammenhänge beobachtet.

Schlüsselwörter: Kinetik, Dressur, Richter, Note, Dressuraufgabe

\section{Introduction}

Some authors studied stride characteristics in dressage according to the results in competition. For example, Devel and Park(1990) showed a correlation between the speed of the extended trot and the stride length for the elite dressage horses in the Seoul olympics. Clayton(1997) described collected trot, passage and piaffe at the Barcelona Olympics. These films recorded during competition were considered as references to study the movement of the best dressage horses. Holmstöm(1994) compared the kinematic characteristics of the trot of horses divided in two groups according to their score obtained at official performance test. Means of gait scores at official performance test were references to compare a good and a poor gait. Back(1994) compared kinematic parameters of gait and the score in which suppleness, strength and length were judged. The objective results measured on treadmill were similar to the rank given by the judge.

In order to judge dressage tests, characteristics of gait and figures have been described in international dressage rules (Anon 1999). All dressage movements are marked on the judges' sheets. Collective marks are awarded for paces, impulsion, submission and the rider's position and seat. Some of them can be given a coefficient. According to dressage rules, qualities of dressage horse should be revealed by the regularity of paces, lightness and cadence. Some of these qualities could be measured and the purpose of this study was to demonstrate the relationship between the gait measurement and judge marks. 


\section{Materials and methods}

Sixteen dressage tests performed by ten young horses were recording by the gait analysis system Equimetrix $\mathrm{tm}$. They were 4 years old $n=5), 5$ years old $(n=1)$ and 6 years old $(n=4)$. They performed tests according to dressage rules for young horses. Some of them performed two tests. Nine dressage tests of more experienced horses were also recorded. This group was composed of three 7 year olds, two 8 year old horses, two 9 year old horses, one 11 year olds and one 13 year old horse. These dressage tests were the Prix St Georges, a middle level test. The gait analysis system recorded horses' accelerations at the same time of marking judges during competition

\section{Gait analysis system}

The gait analysis system Equimetrix 1 was described in the article "the trot characteristics during the first three years of dressage training". It was composed of an acceleration transducer connected to a small data logger which had been used previously in dressage test (Biau et al. 2002). The transducer was composed of two orthogonal accelerometers which measured the thorax acceleration continuously along the dorsoventral and longitudinal axes of the horse. It was fixed on the girth of the saddle against the sternum. This location was adapted to record general information about kinetics of the gait. It was located between the right and left muscles pectoralis ascendens about $60 \mathrm{~cm}$ down and front to the horse's center of gravity (Galloux and Barrey 1997). The accelerometers were connected to a small data logger placed into a pocket of the saddle pad. The data acquisition rate was 50 Hertz. After recording, the data was transferred to a computer for analysis. Data was treated by signal analysis procedures developed to extrapolate the dynamic and temporal variables for each test at trot, walk and canter on line.

\section{Stride characteristics}

Stride Frequency

Stride frequency was defined as the number of strides per unit of time and was also equal to the inverse of stride duration. It was usually expressed in strides/s or hertz $(\mathrm{Hz})$ and was measured by detecting the frequency of the major peak of the power spectrum (2xStride frequency) calculated by a Fast Fourier Transform of the dorsoventral acceleration signal.

Stride regularity

The regularity was a sum of the correlation coefficients corresponding to the peaks of the autocorrelation function of the dorsoventral acceleration, measured at a time equal to the half stride and stride duration. It measured the acceleration pattern similarity in the course of time. It was expressed /200).

\section{Stride symmetry}

The symmetry was the correlation coefficient corresponding to the peak of the autocorrelation function of the dorsoventral acceleration, measured at the time equal to half stride duration. It measured the acceleration pattern similarly in the course of time.

\section{Dorsoventral movements}

Dorsoventral displacement

Dorsoventral displacement of the sternum was estimated by a double integration of the dorsoventral acceleration signal. It was expressed in $\mathrm{cm}$.

\section{Dorsoventral activity}

This was obtained integrating the power spectrum obtained by a Fast Fourier Transform from the dorsoventral acceleration signal. This variable measured the dorsoventral activity of suspension and loading of the limbs. This variable increases with the amplitude and frequency of movements along each axis. It was expressed in $\mathrm{g} \approx / \mathrm{Hz}$

\section{Longitudinal movements}

Vector of propulsion

It was the mean acceleration vector, which produced a propulsive work and the percentage of the stride duration when it was applied. It was expressed in $\mathrm{g}$.

\section{Longitudinal activity}

Longitudinal activity was the integral of the module of the power spectrum obtained by FFT from the longitudinal acceleration signal. It measured the amount of deceleration and acceleration along the longitudinal axis of the horse. This variable is related to the breaking and propulsive work.

Vector of braking

It was the mean deceleration vector, which produced a braking work and the percentage of the stride duration when it was applied. It was expressed in $\mathrm{g}$.

Judges' marks

Three marks of judges' sheets were considered:

Movement mark:

All movements were numbered on the judges sheets and each of them had to be marked from 0 to 10

A collective mark:

After the rider's performance, a mark for paces was awarded.

The total score:

The marks were multiplied by the corresponding coefficients. The total score was obtained by adding the total points.

\section{Statistical analysis}

Horses were divided into two groups: a group of young horses composed of ten horses, performed sixteen dressage tests and a group of experienced horses composed of nine horses performed nine dressage tests. A nonparametric test was used because of the abnormal distribution of the marks. A Spearman correlation was calculated between each stride variables and the three marks (movement mark, Collective mark and the total score) for the group of young horses and the group of experimented horses. 
First, a correlation was calculated between movements marks of five judges during a St Georges test. Fifteen competitors have been judged on twenty nine movements. The correlation was calculated on 435 movements marks by judges.

\section{Results}

The distribution of the marks was not normal. The movement mark should reflect the quality of the movement execution. Competitors are marked from 0 to 10 . However, the majority of marks were around two marks (satisfactory and fairly good). The figure 1 represent the distribution of twenty nine movements marks for five judges of fifteen competitors of a St georges. The correlation between the five judges was significant: $R=0.633$ ( $p<0.0001$, for 435 marks).

\section{Young horses dressage (Tables 1, 2 and 3)}

The collective marks were correlated to some stride variables at walk and trot (Tab 1). A walk with a slow stride frequency,

Tab 1 Coefficient of Spearman correlations between stride characteristics and the collective mark (mean of all judges of the test) for young horses.

Koeffizient der Spearman-Korrelation zwischen den Fortbewegungkomponenten und der Gangnote (Durchschnittsnote der fünf Richter) für junge Pferde.

\begin{tabular}{|l|c|c|c|}
\hline $\begin{array}{c}\text { Correlations with Collective } \\
\text { mark of young horses }\end{array}$ & walk & Trot & Canter \\
\hline stride frequency $(\mathrm{nb}$ of stride/s) & $-0.37(\mathrm{p}=0.0004)$ & $-0.21(\mathrm{p}=0.001)$ & $\mathrm{NS}$ \\
\hline stride symmetry $(\%)$ & $0.35(\mathrm{p}=0.0009)$ & $\mathrm{NS}$ & $\mathrm{NS}$ \\
\hline stride regularity $(/ 200)$ & $0.46(\mathrm{p}<0.0001)$ & $\mathrm{NS}$ & $\mathrm{NS}$ \\
\hline dorsoventral displacement $(\mathrm{m})$ & $0.42(\mathrm{p}<0.0001)$ & $0.26(\mathrm{p}<0.0001)$ & $\mathrm{NS}$ \\
\hline dorsoventral activity $\left(\mathrm{g}^{2} / \mathrm{Hz}\right)$ & $0.39(\mathrm{p}=0.0002)$ & $\mathrm{NS}$ & $\mathrm{NS}$ \\
\hline longitudinal activity $\left(\mathrm{g}^{2} / \mathrm{Hz}\right)$ & $\mathrm{NS}$ & $0.17(\mathrm{p}=0.009)$ & $\mathrm{NS}$ \\
\hline vector of propulsion $(\mathrm{g})$ & $\mathrm{NS}$ & $\mathrm{NS}$ & $\mathrm{NS}$ \\
\hline vector of braking $(\mathrm{g})$ & $\mathrm{NS}$ & $\mathrm{NS}$ & $\mathrm{NS}$ \\
\hline
\end{tabular}

a good symmetry, a good regularity a large dorsoventral activity and dorsoventral displacement obtained higher marks. For trot, a good collective mark was associated to a slow stride frequency and an high dorsoventral activity. No variable was correlated to collective marks at the canter.

Tab 2 Coefficient of Spearman correlations between stride characteristics and the movement mark (mean of all judge of the test) for young horses.

Koeffizient der Spearman-Korrelation zwischen den Fortbewegungkomponenten und der Benotung der Dressuraufgabe (Durchschnittsnote der fünf Richter) für junge Pferde.

\begin{tabular}{|l|c|c|c|}
\hline $\begin{array}{c}\text { Correlations with movements } \\
\text { mark of young horses }\end{array}$ & walk & Trot & Canter \\
\hline stride frequency $(\mathrm{nb}$ of stride/s) & $\mathrm{NS}$ & $-0.17(\mathrm{p}=0.0055)$ & $\mathrm{NS}$ \\
\hline stride symmetry $(\%)$ & $0.28(\mathrm{p}=0.009)$ & $\mathrm{NS}$ & $\mathrm{NS}$ \\
\hline stride regularity $(/ 200)$ & $0.42(\mathrm{p}<0.0001)$ & $\mathrm{NS}$ & $\mathrm{NS}$ \\
\hline dorsoventral displacement $(\mathrm{m})$ & $0.37(\mathrm{p}=0.0005)$ & $0.24(\mathrm{p}=0.0002)$ & $0.25(\mathrm{p}=0.0005)$ \\
\hline dorsoventral activity $\left(\mathrm{g}^{2} / \mathrm{Hz}\right)$ & $0.42(\mathrm{p}<0.0001)$ & $0.28(\mathrm{p}=0.0001)$ & $0.28(\mathrm{p}=0.0001)$ \\
\hline longitudinal activity $\left(\mathrm{g}^{2} / \mathrm{Hz}\right)$ & $\mathrm{NS}$ & $0.13(\mathrm{p}=0.04)$ & $0.15(\mathrm{p}=0.04)$ \\
\hline vector of propulsion $(\mathrm{g})$ & $0.44(\mathrm{p}=0.04)$ & $\mathrm{NS}$ & $\mathrm{NS}$ \\
\hline vector of braking $(\mathrm{g})$ & $0.22(\mathrm{p}=0.04)$ & $\mathrm{NS}$ & $\mathrm{NS}$ \\
\hline
\end{tabular}

The movement mark (Tab 2) was correlated with some variables at the three gaits. The walk was rewarded for its good symmetry, regularity, dorsoventral activity and its good propulsive and braking work. At trot, we obtained a good mark for a slow stride frequency, a good longitudinal and dorsoventral activitiy like the collective mark. A well marked canter movement was a canter with a good longitudinal and dorsoventral activities.

The total score (Tab 3) showed the importance of trot. The correlations with collective marks and movement marks at walk and movements marks at canter had disappeared. The

Tab 3 Coefficient of Spearman correlations between stride characteristics and the total score for young horses.

Koeffizient der Spearman-Korrelation zwischen den Fortbewegungkomponenten und dem Gesamtergebnis (Durchschnittsnote der fünf Richter) für junge Pferde.

\begin{tabular}{|l|c|c|c|}
\hline $\begin{array}{c}\text { Correlations with total score } \\
\text { of young horses }\end{array}$ & walk & trot & Canter \\
\hline stride frequency $(\mathrm{nb}$ of stride/s) & $\mathrm{NS}$ & $-0.16(\mathrm{p}=0.005)$ & $\mathrm{NS}$ \\
\hline stride symmetry $(\%)$ & $\mathrm{NS}$ & & $\mathrm{NS}$ \\
\hline stride regularity $(/ 200)$ & $\mathrm{NS}$ & $0.12(\mathrm{p}=0.04)$ & $\mathrm{NS}$ \\
\hline dorsoventral displacement $(\mathrm{m})$ & $\mathrm{NS}$ & $0.25(\mathrm{p}<0.0001)$ & $\mathrm{NS}$ \\
\hline dorsoventral activity $\left(\mathrm{g}^{2} / \mathrm{Hz}\right)$ & $\mathrm{NS}$ & & $\mathrm{NS}$ \\
\hline longitudinal activity $\left(\mathrm{g}^{2} / \mathrm{Hz}\right)$ & $\mathrm{NS}$ & $0.18(\mathrm{p}=0.0018)$ & $\mathrm{NS}$ \\
\hline vector of propulsion $(\mathrm{g})$ & $0.32(\mathrm{p}=0.04)$ & $\mathrm{NS}$ & $\mathrm{NS}$ \\
\hline vector of braking $(\mathrm{g})$ & $\mathrm{NS}$ & $0.15(\mathrm{p}=0.01)$ & $\mathrm{NS}$ \\
\hline
\end{tabular}

total score was correlated to the stride frequency, the symmetry, the regularity, the dorsoventral displacement, the longitudinal activity and the braking work.

\section{Experienced horses dressage tests (Tables 4 and 5)}

For experienced horses dressage tests, no marks were correlated with variables at walk (Tables 4 and 5). No movement mark was correlated with walk, trot and canter variables. A regular trot, with longitudinal activity, particularly braking work, had a good collective mark (Tab 4). The trot regularity

Tab 4 Coefficient of Spearman correlations between stride characteristics and the collective mark (mean of all judge of the test) for experienced horses.

Koeffizient der Spearman-Korrelation zwischen den Fortbewegungkomponenten und der Gangnote (Durchschnittsnote der fünf Richter) für erfahrene Pferde.

\begin{tabular}{|l|c|c|c|}
\hline $\begin{array}{c}\text { Correlations with Collective } \\
\text { mark of experienced horses }\end{array}$ & Walk & Trot & Canter \\
\hline stride frequency $(\mathrm{nb}$ of stride/s) & $\mathrm{NS}$ & $\mathrm{NS}$ & $\mathrm{NS}$ \\
\hline stride symmetry $(\%)$ & $\mathrm{NS}$ & $\mathrm{NS}$ & $\mathrm{NS}$ \\
\hline stride regularity $(/ 200)$ & $\mathrm{NS}$ & $0.23(\mathrm{p}=0.01)$ & $0.42(\mathrm{p}=0.002)$ \\
\hline dorsoventral displacement $(\mathrm{m})$ & $\mathrm{NS}$ & $\mathrm{NS}$ & $\mathrm{NS}$ \\
\hline dorsoventral activity $\left(\mathrm{g}^{2} / \mathrm{Hz}\right)$ & $\mathrm{NS}$ & $\mathrm{NS}$ & $\mathrm{NS}$ \\
\hline longitudinal activity $\left(\mathrm{g}^{2} / \mathrm{Hz}\right)$ & $\mathrm{NS}$ & $-0.25(\mathrm{p}=0.004)$ & $\mathrm{NS}$ \\
\hline vector of propulsion $(\mathrm{g})$ & $\mathrm{NS}$ & $\mathrm{NS}$ & $\mathrm{NS}$ \\
\hline vector of braking $(\mathrm{g})$ & $\mathrm{NS}$ & $-0.25(\mathrm{p}=0.006)$ & $\mathrm{NS}$ \\
\hline
\end{tabular}

Tab 5 Coefficient of Spearman correlations between stride characteristics and the movement mark (mean of all judge of the test) for experienced horses.

Koeffizient der Spearman-Korrelation zwischen den Fortbewegungkomponenten und der Hufschlagfigurenaufgabentnote (Durchschnittsnote der fünf Richter) für Pferde mit Erfahrung.

\begin{tabular}{|l|c|c|c|}
\hline $\begin{array}{c}\text { Correlations with total score } \\
\text { of experienced horses }\end{array}$ & Walk & trot & Canter \\
\hline stride frequency $(\mathrm{nb}$ of stride/s) & $\mathrm{NS}$ & $\mathrm{NS}$ & $\mathrm{NS}$ \\
\hline stride symmetry $(\%)$ & $\mathrm{NS}$ & $\mathrm{NS}$ & $\mathrm{NS}$ \\
\hline stride regularity $(/ 200)$ & $\mathrm{NS}$ & $0.23(\mathrm{p}=0.008)$ & $0.56(\mathrm{p}<0.0001)$ \\
\hline dorsoventral displacement $(\mathrm{m})$ & $\mathrm{NS}$ & $0.19(\mathrm{p}=0.001)$ & $\mathrm{NS}$ \\
\hline dorsoventral activity $\left(\mathrm{g}^{2} / \mathrm{Hz}\right)$ & $\mathrm{NS}$ & $\mathrm{NS}$ & $\mathrm{NS}$ \\
\hline longitudinal activity $\left(\mathrm{g}^{2} / \mathrm{Hz}\right)$ & $\mathrm{NS}$ & $\mathrm{NS}$ & $\mathrm{NS}$ \\
\hline vector of propulsion $(\mathrm{g})$ & $\mathrm{NS}$ & $-0.48(\mathrm{p}<0.0001)$ & $-0.29(\mathrm{p}=0.01)$ \\
\hline vector of braking $(\mathrm{g})$ & $\mathrm{NS}$ & $\mathrm{NS}$ & $\mathrm{NS}$ \\
\hline
\end{tabular}

was correlated with the total score. The regularity was correlated with the marks obtained at the canter. It was correlated with a good collective mark and we were able to trace it on the level with total score. 


\section{Achten Sie bei der Kaufuntersuchung}

auf die neuen gesetzlichen Regelungen bezüglich der des Beginns der Veriährung und der Daver der Gewährsfrist

und vertraven Sie

im Übrigen auf den

Pferdeheilkunde-Vertrag

über die Untersuchung eines Pferdes 


\section{Discussion}

Judges are marked from 0 to 10,0 being the lowest when nothing of the required movements has been performed and 10 is the highest mark for an excellent movement. Range of marks was not used. However, the results of the Spearman correlation in the five St Georges judges showed that the judgement was quite similar.

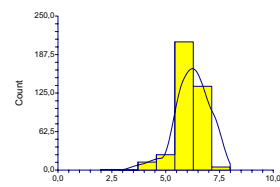

Juge 1
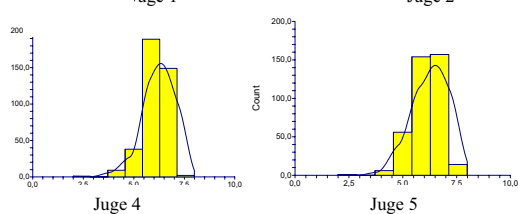

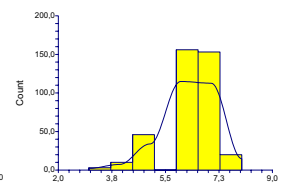

Juge 3

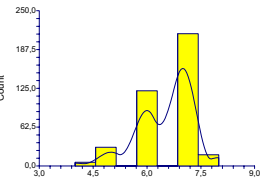

uge 2
Fig 1 Distribution of St Georges (15 competitors) marks (29 marks) for five judges.

Verteilung der Benotungen einer "St Georges-Prüfung" durch die fünf Richter.

Some studies described correlations between kinematic variables and judge scores. There were significant correlations between judgement and stride duration (Holmström 1994; Back 1994), scapula rotation and fetlock flexion during the stance phase (Back 1994), and positive diagonal advanced placement (Holmström 1994). The present study confirmed the relationships between judgement and stride duration for young horses. A slow stride frequency at walk and trot was appreciate.

The requirements of the three gaits in young horses were identified:

- The trot should be slow with a good dorsoventral displace ment and a good longitudinal activity.

- The walk should be slow, regular, symmetric, with a good dorsoventral activity and a good dorsoventral displacement. These results related to the importance of the walk to buy a horse. Another study in young dressage horses described that the walk in hand should have a slow stride frequency and a high dorsoventral displacement (Barrey 2002).

- A movement well performed at the canter referred to lon gitudinal and dorsoventral activities. However, these varia bles were not related to the collective mark.

The total score reflected only the characteristics of trot.

The lack of correlations for experienced horses referred to the diversity of movements with more technical and training input. The judgment of the collected gait differs from judgment of more natural gaits in young horses. These results showed that a young horse was judged more on the basis of its own gait characteristics than experienced horses. According to dressage rules, judgment is a way to verify dressage ability and gait quality. Experienced horses were judged on different basis by considering submission, the rider's position and seat, aids, harmony and lightness. However, there was a coherence between judges in spite of the not normal distribution of the marks and a few correlation between marks and gait variables.

\section{Conclusion}

Judgment of dressage tests is based on criteria described in the dressage rules and some of them were significantly correlated with gait variables measured by the gait analysis system: stride frequency, regularity and dorsoventral displacement. There were more correlations observed in young horses group than in experienced horses group.

\section{Manufacturer's address}

${ }^{1}$ Equimetrix $^{\mathrm{TM}}$ : distributed by Centaure Metrix, 6 Rue Marrier 77300 Fontainebleau, France. www.centaure-metrix.com

\section{Literature}

Anon (1999) Rules of dressage, Federation Equestre Internationale (FEl)

Back W., Barneveld A., Bruin G., Schamhardt H. C. and Hartman W. (1994): Kinematic detection of superior gait quality in young trotting warmbloods. Vet Quart 16, Suppl 2, 91-96

Barrey E. and Galloux P. (1997): Analysis of the equine jumping technique by accelerometry. Equine vet. J. Suppl. 23, 45-49

Barrey E., Evans S. E., Evans D. L., Curtis R. A., Quiton R. and Rose R. J. (2001): Locomotion evaluation for racing in thoroughbreds. Equine vet. J. Suppl. 33 , 99-103

Barrey E., Desliens F., Biau S., Lemaire S., Poirel D., Rivero J. L. L. and Langlois B. (2002): Comparison of the walk, trot and conformation in young horses bred for dressage. Equine vet. J. Suppl. 34, 319-324

Biau S., Lemaire S. and Barrey E. (2002): Analysis of gait transitions in dressage horses using wavelet analysis of dorsoventral acceleration. Pferdeilkunde 18, 343-350

Biau S., Couve O., Lemaire S. and Barrey E. (2002): The effect of reins on kinematic variables of locomotion. Equine Vet. J. Suppl 34, 359-362

Clayton H. M. (1997) Classification of collected trot, passage and piaffe based on temporal variables. . Equine vet. J. Suppl. 23, 5457

Devel N. R. and Park J. (1990) The gait patterns of Olympic dressage horses. Int J. Sport Biomech. 6, 198-226

Galloux P. and Barrey E. (1997). Components of the total kinetic moment in jumping horses. Equine vet. J. Suppl 23, 41-44

Holmstrom M., Fredricson I. and Drevemo S. (1994): Biokinematic differences between riding horses judged as good and poor at the trot. Equine Vet. J. Suppl. 17, 51-56

\section{Dr. Sophie Biau}

Ecole Nationale d'Equitation Terrefort BP 207, F-49400 Saumur, France. recherche-ene@cadrenoir.tm.fr

\section{Pferdeheilkunde Forum 2004 - Berliner Fortbildungstage}

